\title{
BUDIDAYA UDANG VANAME (LITOPENAEUS VANNAMEI) SUPER INTENSIF DENGAN PADAT TEBAR BERBEDA MENGGUNAKAN SISTEM ZERO WATER DISCHARGE.
}

\author{
Rahim*, Muhammad Reza Almi Rukmana, Anti Landu dan Asni \\ Program Studi Ilmu Perikanan, Fakultas Pertanian, Perikanan dan Peternakan \\ Universitas Sembilanbelas November Kolaka, Kolaka \\ *Koresponden penulis :rahimspimsi@gmail.com
}

\begin{abstract}
Abstrak
Penelitian ini bertujuan untuk mengetahui laju pertumbuhan,kelangsungan hidup dan rasio konversi pakan pada budidaya udang vaname super intensif dengan padat tebar berbeda menggunakan sistem Zero Water Discharge(ZWD). Penelitian ini dilaksanakan pada bulan Agustus-Oktober 2018, di Hatchery Windu Lestari Kel. Wolulu Kec. Watubangga Kab. Kolaka. Hewan uji yang digunakan adalah Benur udang vaname PL 10 yang diperoleh dari hatchery komersil. Penelitian ini menggunakan metode Rancangan Acak Lengkap (RAL) dengan tiga perlakuan dan tiga ulangan. Perlakuan A : padat tebar $40 \mathrm{ekor} / 0.1 \mathrm{~m}^{3}$, perlakuan B : padat tebar 50 ekor $/ 0.1 \mathrm{~m}^{3}$, perlakuan C : padat tebar $60 \mathrm{ekor} / 0.1 \mathrm{~m}^{3}$. Parameter yang diukur adalah kelangsungan hidup, pertumbuhan berat mutlak, laju pertumbuhan spesifik, rasio konversi pakan dan kualitas air. Hasil analisis statistik dengan uji ANOVA menunjukkan bahwa padat tebar berbeda signifikan terhadap pertumbuhan berat mutlak, laju pertumbuhan spesifik dan rasio konversi pakan,namum tidak signifikan terhadap kelangsungan hidup dan parameter fisika-kimia air pada budidaya udang vaname super intensif menggunakan sistem $Z W D$. Pertumbuhan berat mutlak tertinggi pada perlakuan A (7,54 $\pm 0,15 \mathrm{~g}$ /ind), perlakuan $\mathrm{B}(6,47 \pm 0,10 \mathrm{~g} /$ ind $)$ dan perlakuan $\mathrm{C}(6,07 \pm 0,10 \mathrm{~g} / \mathrm{ind})$. Laju pertumbuhan spesifik tertinggi pada perlakuan $\mathrm{A}(7,90 \pm 0,03 \%$ /hari), perlakuan $\mathrm{B}(7,68 \pm 0,02 \%$ /hari) dan perlakuan $\mathrm{C}(7,59 \pm 0,02$ $\% /$ hari). Rasio konversi pakan terkecil pada perlakuan A $(1,54 \pm 0,03)$, perlakuan B $(1,56 \pm 0,02)$ dan perlakuan B $(1,62 \pm 0,02)$.
\end{abstract}

Kata Kunci : Udang vaname, Padat Tebar, Zero Water Discharge, Kualitas Air.

\begin{abstract}
This study aims to determine the growth rate, survival and feed conversion ratio in super intensive vaname shrimp culture with different stocking densities using the Zero Water Discharge system. This research was conducted in August-October 2018, at Hatchery Windu Lestari Kel. Wolulu Kec. Watubangga Kab. Kolaka. The test animal used was PL 10 vaname shrimp fry obtained from commercial hatcheries. This study used a completely randomized design (CRD) method with three treatments and three replications. Treatment A: stocking density 40 heads $/ 0.1 \mathrm{~m}^{3}$, treatment B: stocking density 50 heads $/ 0.1 \mathrm{~m}^{3}$, treatment $\mathrm{C}$ : stocking density 60 heads $/ 0.1 \mathrm{~m}^{3}$. The parameters measured were survival, absolute weight growth, specific growth rate, feed conversion ratio and water quality. The results of statistical analysis using the ANOVA test showed that the stocking density was significantly different on the growth of absolute weight, specific growth rate and feed conversion ratio, but not significant on the survival and physicochemical parameters of water in super intensive vaname shrimp culture using the ZWD system. Thehighest absolute weight growth was in treatment $\mathrm{A}(7.54 \pm 0.15 \mathrm{~g} / \mathrm{ind})$, treatment $\mathrm{B}(6.47 \pm 0.10 \mathrm{~g} / \mathrm{ind})$ and treatment $\mathrm{C}(6.07 \pm 0.10$ $\mathrm{g} /$ ind).The highest specific growth rate was in treatment $\mathrm{A}(7.90 \pm 0.03 \% /$ day $)$, treatment $\mathrm{B}(7.68 \pm 0.02 \% / \mathrm{day})$ and treatment $\mathrm{C}(7.59 \pm 0.02 \% / \mathrm{day})$. The smallest feed conversion ratio was in treatment $\mathrm{A}(1.54 \pm 0.03)$, treatment $\mathrm{B}$ $(1.56 \pm 0.02)$ and treatment $\mathrm{B}(1.62 \pm 0.02)$.
\end{abstract}

Keyword : Vaname shrimp, stocking density, zero water discharge, water quality. 


\section{PENDAHULUAN}

Udang vaname (Litopenaeus vannamei) merupakan salah satu jenis udang introduksi yang akhir-akhir ini banyak diminati, karena memiliki banyak keunggulan seperti tahan terhadap penyakit, pertumbuhan cepat (masa pemeliharaan 100-110 hari), tahan terhadap perubahan lingkungan, padat tebar tinggi, sintasan selama pemeliharaan tinggi dan rasio konversi pakan (FCR)nya rendah. Budidaya udang memberikan kontribusi terbesar sebagai penghasil devisa Negara disektor perikanan. Produksi udang nasional Indonesia pada tahun 2017 mencapai 919.959 ton.Produksi udang di Provinsi Sulawesi Tenggara pada tahun 2017 mencapai 130.653 Ton dan produksi perikanan budidaya Kab. Kolaka pada tahun 2017 mencapai 16.477 Ton [1].

Meskipun produksi udang di Indonesia meningkat, sampai saat ini total produksi udang vaname di Indonesia masih belum dapat memenuhi permintaan pasar domestik maupun pasar internasional. Hal ini disebabkan karena hasil budidaya udang vaname di Indonesia didomansi budidaya secara konvensional. Budidaya udang vaname secara konvensional cenderung tidak memperhatikan pengelolahan kualitas air. Kualitas air yang buruk dapat menimbulkan berbagai macam penyakit sehingga berdampak buruk bagi lingkungan hidup udang sehingga berpengaruh pada kelangsungan hidup udang. Disamping itu, rendahnya padat penebaran menjadi salah satu penyebab menurunnya produksi udang.

Salah satu sistem budidaya udang vaname saat ini yang mampu menjaga kualitas air adalah
Zero Water Discharge. Zero Water Discharge merupakan sistem pemeliharaan udang yang memanfaatkan mikroba bakteri menguntungkan dan mikroalga didalam menjaga kualitas air selama masa pemeliharaan. Pemanfaatan mikroba bakteri menguntungkan dan mikroalga dapat mengurangi senyawa - senyawa yang bersifat racun menjadi bahan yang bermanfaat serta mengurangi senyawa $\mathrm{N}$ inorganik pada media budidaya [2].

Teknologi budidaya udang vaname Super Intensif menjadi orientasi teknologi budidaya masa depan dengan menggunakan konsep low volume high density. Super Intensif merupakan teknologi dengan padat penebaran udang yang tinggi dengan luas lahan yang sempit $\left(1.000 \mathrm{~m}^{2}\right)$, beban limbah minimal, memiliki tendon air bersih dan pengelolahan buangan air limbah. Kunci keberhasilan teknologi super intensif dengan menerapkan 5 subsistem budidaya, yaitu penggunaan benih berkualitas, penanganan kesehatan dan lingkungan, penerapan teknologi budidaya yang sesuai, penggunaan sarana dan prasarana budidaya yang standar serta menerapkan manajemen usaha moderen [3].

Penelitian udang vaname super intensif dengan padat penebaran tinggi telah dilakukan peneliti sebelumnya dengan padat penebaran 390500 ekor $/ \mathrm{m}^{3}$ [4], 200-400 ekor/m $\mathrm{m}^{3}$ [5]. Hasil dari penelitian [5], menerangkan bahwa secara biologi padat tebar 400 ekor $/ \mathrm{m}^{3}$ diperoleh hasil yang terbaik untuk mendukung kelangsungan hidup $(70.59 \pm 6.15 \%$,$) , laju pertumbuhan spesifik (4.40$ $\pm 0.25 \%$ berat udang/hari) dan rasio konversi pakan (1.14 \pm 0.14). Hasil penelitian [11],menerangkan bahwa padat tebar $500 \mathrm{ekor} / \mathrm{m}^{3}$ 
secara biologi masih mendukung kelangsungan hidup (78.8\%), laju pertumbuhan spesifik (1.95g/minggu) dan rasio konversi pakan (1.44). Padat penebaran tinggi yang diaplikasikan pada budidaya super intensif diharapkan akan diikutidengan peningkatan produksi, namun ada batastertentu dimana daya dukung tambak tidak lagi mampumenunjang kehidupan udang dalam jumlah biomassatertentu. Oleh karena itu, diperlukan penentuan padatpenebaran optimal agar produksi udang maksimal dengan biaya produksi yang rendah.Berdasarkan uraian diatas, maka perlu dilakukan penelitian mengenai budidaya udang vaname super intensif dengan padat tebar berbeda menggunakan sistem Zero Water Discharge.

\section{METODOLOGI}

Penelitian ini dilaksanakan pada bulan Agustus - Oktober 2018, bertempat di Hatchery Windu Lestari, Kelurahan Wolulu, Kecamatan Watubangga, Kabupaten Kolaka Provinsi Sulawesi Tenggara.Udang uji yang digunakan adalah benur udang putih PL 10 yang berasal dari Hatchery PT. Esaputlii Prakarsa Utama Kab.

Barru Propinsi Sulawesi Selatan yang diaklimatisasi terlebih dahulu selama 5 (lima) hari dengan berat rata-rata 0,03 g/ekor. Penelitian ini menggunakan Rancangan Acak Lengkap (RAL) yang terdiri dari 3 perlakuan dan tiga ulangan dengan padat tebar berbeda, meliputi ; perlakuan A :padat tebar 40 ekor $/ 0.1 \mathrm{~m}^{3}$, perlakuan B : padat tebar 50 ekor $/ 0.1 \mathrm{~m}^{3}$, perlakuan $\mathrm{C}$ : padat tebar 60 ekor/ $/ 0.1 \mathrm{~m}^{3}$. Wadah penelitian menggunakan tangki air dengan volume air 100 liter, total udang uji yang digunakan adalah 450 ekor.

\section{Prosedur Penelitian}

A. Pengkondisian sistem zero water discharge (ZWD)

Proses pengkondisan media budidaya dengan sistem ZWD meliputi :

1. Wadah pemeliharaan udang vaname yang digunakan berupa tangki air dengan kapasitas volume $100 \mathrm{~L}$ sebanyak 9 buah dilengkapi dengan aerasi sebagai suplai oksigen.

2. Pengkondisian media budidaya dilakukan selama 10 hari dengan penambahan probiotik sebanyak $10 \mathrm{ml}$, mikroalgaSkeletonema costacum $500 \mathrm{ml}$, pakan komersil 10 gram dan gula merah $15 \mathrm{ml}$ sebagai sumber karbon.

3. Selama proses pengkondisian, dilakukan pengukuran kadar Total Amonium Nitrogen (TAN) setiap 3 hari sekali dengan menggunakan Test Kit sampai pada kadar TAN dibawah 0,05 mg/L.

4. Desain sistem Zero Water Discharge pada penelitian ini terlihat pada Gambar 3.

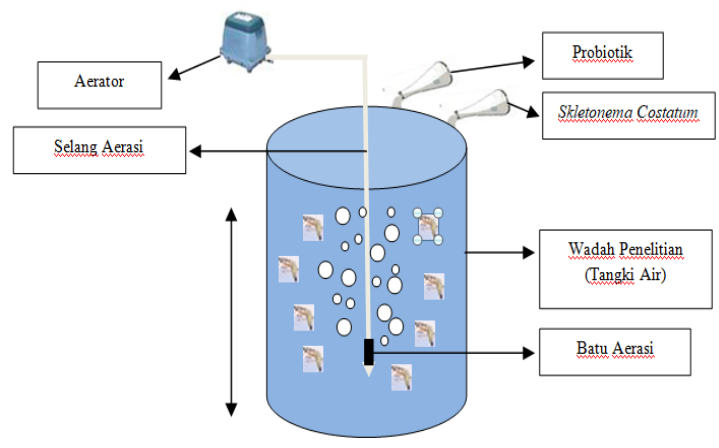

Gambar 4. Desain Sistem ZWD untuk Budidaya Udang Vaname 
B. Prosedur Budidaya

1. Setelah proses pengkondisian media budidaya sistem ZWD, udang ditebar kedalam wadah penelitian sesuai perlakuan yang diberikan.

2. Pemberian Probiotik dilakukan setiap minggu dengan dosis $10 \mathrm{ml}$ dengan kandungan bakteriBacillus $s p$ ,Nitrosomonas $s p$ dan Nitrobacter $s p$.

3. Pemberian mikroalga $S$. costacum dilakukan setiap minggu dengan dosis 30 $\mathrm{ml}$.

4. Setiap minggu dilakukan pengukuran kualitas air dan sampling udang disetiap wadah untuk megetahui pertambahan berat serta sebagai bahan acuan untuk pemberian pakan.

5. Pemberian pakan dilakukan pada hari ke 7 setelah udang ditebar kewadah dengan dosis pemberian $12-6 \%$ dari biomassa udang dengan kandungan protein pakan $30 \%$.

6. Pemberian pakan dilakukan sebanyak 2 kali sehari pada bulan pertama (pagi dan sore) pukul 08.00 dan 17.00 dan 3 kali sehari pada bulan kedua (pagi,siang dan malam) pukul 08.00, 14.00 dan 19.00, ukuran pakan disesuaikan dengan berat udang.

7. Penyiponan dilakukan setiap minggu untuk membersihkan sisa pakan dan feces udang yang mengendap pada dasar wadah budidaya.

\section{Pengukuran Parameter}

Parameter yang diamati selama penelitian meliputi parameter fisika-kimia air dan parameter biologi. Parameter fisika-kimia air, seperti $\mathrm{pH}$, suhu, DO diukur secara insitu setiap minggu, sedangkan kadar TAN (Total Amonia Nitrogen) diukur menggunakan test KIT setiap 3 hari. Untuk parameter biologi seperti, pertumbuhan, kelangsungan hidup dan feed convertion ratio, dihitung dengan rumus :

1. Kelangsungan hidup (\%)

$$
\mathrm{SR}(\%)=\frac{\mathrm{Nt}}{\mathrm{No}} \times 100
$$

2. Laju pertumbuhan spesifik (\% hari)

$$
\operatorname{SGR}(\%)=\left[\sqrt[t]{\frac{\mathrm{Wt}}{\mathrm{Wo}}}-1\right] \times 100
$$

3. Biomass $=(\mathrm{D})(\mathrm{W})$

4. Feed conversion ratio (FCR)

$$
(\mathrm{FCR})=\sum \mathrm{Wf} / \Delta \times 100 \%
$$

Keterangan:

N0 : jumlah udang pada awal kultur (ind)

$\mathrm{Nt} \quad$ : jumlah udang pada akhir kultur (ind)

Wt : berat udang pada akhir kultur $(\mathrm{g})$

W0 : berat udang pada awal kultur $(\mathrm{g})$

t : lama pemeliharaan (hari)

D : densitas (ind/kolam)

$\hat{\mathrm{W}}$ : berat rata-rata per individu (g/ind)

$\Sigma \mathrm{Wf}$ : total pakan yang diberikan selama kultur (g)

$\Delta \mathrm{W} \quad$ : total berat udang pada masing-masing bak $(\mathrm{g})$

Analisis Data

Untukmengetahuipengaruh setiap perlakuan,maka data dianalisismenggunakan analisis ANOVA satu arah dengan nilai tingkat kepercayaan $5 \%$

$(\mathrm{P}<0,05)$.Datadianalisisdenganbantuan softwareIBMSPSSStatistik21.

\section{HASIL DAN PEMBAHASAN}

\section{Parameter Biologi}

Data hasil pengamatan paramteter biologi meliputi pertumbuhan mutlak, laji pertumbuhan spesifik, kelangsungan hidup dan feed coversio ratio 
udang vaname yang dibudidayakan dengan sistem zero water discharge (ZWD) dengan padat tebar berbeda disajikan pada Tabel 1. Hasil pengamatan ini (Tabel 1) menunjukkan bahwa pertumbuhan mutlak udang vaname menurun seiring dengan meningkatnya padat tebar. Pertumbuhan mutlak tertiinggi dijumpai pada perlakuan A (padat tebar 40 ekor/0,1 m³) dan berbeda nyata dengan perlakuan lainnya $(\mathrm{P}<0,05)$, sedangkan pertumbuhan mutlak udang vaname pada perlakuan padat tebar 50 dan 60 ekor/0,1 $\mathrm{m}^{3}$ juga menunjukkan hasil yang berbeda nyata $(\mathrm{P}<0,05)$. Hal serupa juga terlihat pada pengamatan laju pertumbuhan spesifik, perlakuan padat tebar menunjukkan hasil berbeda nyata untuk setiap perlakuan $(\mathrm{P}<0,05)$. Namun perlakuan $\mathrm{B}$ (padat tebar 50 ekor/0,1 $\mathrm{m}^{3}$ ) tidak menunjukkan hasil yang signifkan terhadap perlakuan A (padat tebar 40 ekor/0,1 $\mathrm{m}^{3}$ ) dan C (padat tebar 60 ekor/0,1 m³).

Laju pertumbuhan spesifik tertinggi udang vaname yang dibudidayakan dengan sistem ZWD dijumpai pada perlakuan A.Tingginya pertumbuhan udang vaname yang dijumpai pada setiap perlakuan dengan padat tebar berbeda menunjukkan bahwa sistem ZWD dengan peran mikroba dalam siklus nutrient mampu mendukung kinerja udang vaname meskipun dengan kepadatan tinggi [6], [2]. Penelitian ini juga menunjukkan pertumbuhan yang lebih baik dibanding penelitian sebelumnya yang dilakukan oleh[2] pada media air asing dengan pertumbuhan rata-rata $8,24 \mathrm{~g}$ selama 90 hari pemeliharaan .

Hasil pengamatan tingkat kelangsungan hidup dan feed conversion ratioudang vaname yang dibudidayakan dengan sistem ZWD padat tebar berbeda (Tabel 1) menunjukkan tidak adanya perbedaan nyata untuk setiap perlakuan $(\mathrm{P}>0,05)$. Kelangsungan hidup tertinggi dijumpai pada perlakuan A(padat tebar 40 ekor/ $0,1 \mathrm{~m}^{3}$ ) yaitu sebesar 9,17\% . Sementara itu, nilai FCR terendah dijumpai pada perlakuan A (padat tebar 40 ekor/ $0,1 \mathrm{~m}^{3}$ ) yaitu sebesar 1,54 dan berbeda nyata dengan perlakuan C (padat tebar 60 ekor/0,1 $\mathrm{m}^{3}$ ). Kelangsungan hidup yang diperoleh pada penelitian ini menunjukkan hasil tidak berbeda nyata untuk setiap perlakuan dengan nilai diatas $86 \%$. Tingginya kelangsungan hidup yang dijumpai pada penelitian ini disebabkan oleh kinerja sistem ZWD yang cukup baik. Sistem ZWD terbukti mampu mengontrol kualitas air, menekan kehadiran bakteri pathogen dan menyediakan pakan alami bagi organisme budidaya dalam bentuk flok[7], [8].

Padat tebar tertinggi pada penelitian ini terdapat pada perlakuan $\mathrm{C}$ yaitu 60 ekor/ $0,1 \mathrm{~m}^{3}$ atau setara dengan padat tebar 600 ekor $/ \mathrm{m}^{3}$ dengan tingkat kelangsungan hidup $86,01 \%$. Hasil penelitian ini tidak berbeda jauh dengan hasil penelitian sebelumya dengan pada tebar 400 ekor $/ \mathrm{m}^{3}$ kelangsungan hidup 90,82\% [2] dan penelitian [9], dengan padat tebar 1250 ekor/ $\mathrm{m}^{2}$ kedalaman air 1,8 $\mathrm{m}$ atau setara dengan $694 \mathrm{ekor} / \mathrm{m}^{3}$ menggunakan kolam terpal mampu mencapai kelangsungan hidup 79,1\%. Selain tingkat kelangsungan hidup, parameter biologi yang penting diperhatikan pada budidaya udang vaname adalah Feed Conversion Ratio (FCR). Hasil penelitian ini menunjukkan nilai FCR berada pada pada kisaran 1,5-1,6 dari semua perlakuan. Nilai FCR ini masih berada pada kisaran yang layak untuk budidaya udang vaname dengan padat tebar tinggi. Penerapan sistem 
ZWD pada budidaya udang vaname melalui penambahan probiotik dan karbon mampu mengstimulai pembentukan flok sebagai pakan alami, sehingga mampu mengurangi kebutuhan pakan buatan dan tetap mendukung pertumbuhan udang vaname. Penelitian tentang budidaya udang vaname sistem super intensif dengan padat tinggi baik menggunakan sistem ZWD, bioflok atau sistem lainnya menunjukkan nilai FCR pada kisaran 1.2-1.5 [10], [11], [12].

\section{Parameter Fisika-Kimia Air}

Untuk pengamatan parameter fisikakimia air selama proses budidaya udang vaname dengan padat tebar berbeda sistem zero water discharge dapat dilihat pada Tabel 2. Nilai rata-

Tabel 1. Pertumbuhan mutlak, laju pertumbuhan spesifik, kelangsungan hidup dan feed conversion ratio(FCR) udang vaname yang dibudidayakan dengan sistem zero water discharge dengan padat tebar berbeda.

\begin{tabular}{lccc}
\hline \multirow{2}{*}{ Parameter } & \multicolumn{3}{c}{ Perlakuan } \\
\cline { 2 - 4 } & A & B & C \\
Pertumbuhan mutlak (g/ind) & $7,54 \pm 0,15^{\mathrm{a}}$ & $6,47 \pm 0,10^{\mathrm{b}}$ & $6,07 \pm 0,10^{\mathrm{c}}$ \\
Laju pertumbuhan spesifik (\%/hari) & $7,90 \pm 0,03^{\mathrm{a}}$ & $7,68 \pm 0,02^{\mathrm{ab}}$ & $7,59 \pm 0,02^{\mathrm{b}}$ \\
Kelangsungan hidup (\%) & $89,17 \pm 2,89^{\mathrm{a}}$ & $86,67 \pm 3,05^{\mathrm{a}}$ & $86,01 \pm 2,55^{\mathrm{a}}$ \\
Feed conversion ratio $(\mathrm{FCR})$ & $1,54 \pm 0,03^{\mathrm{a}}$ & $1,56 \pm 0,02^{\mathrm{a}}$ & $1,62 \pm 0,02^{\mathrm{b}}$ \\
\hline
\end{tabular}

Keterangan : Nilai merupakan rerata SD $(n=3)$. Superskrip alphabet yang berbeda menunjukkan nilai berbeda nyata antara pada tebar berbeda $(\mathrm{P}<0,05)$, ANOVA satu arah).

Description : Values are the mean $\pm \mathrm{SD}(\mathrm{n}=3)$. Different alphabet superscript showed significant difference values between different stocking densities ( $\mathrm{P}<0.05$, one-way ANOVA)

Tabel 2. Kisaran dan nilai rata-rata dari parameter fisika-kimia air pada setiap perlakuan selama 70 hari periode budidaya.

\begin{tabular}{cccc}
\hline $\begin{array}{c}\text { Parameter fisika-kimia } \\
\text { air }\end{array}$ & Perlakuan & Kisaran & $\begin{array}{c}\text { Rata-rata } \pm \text { standar } \\
\text { deviasi }\end{array}$ \\
\hline Oksigen terlarut (mg/L) & A & $6,24-8,89$ & $7,37 \pm 0,70^{\mathrm{a}}$ \\
& B & $6,03-10,41$ & $7,45 \pm 1,00^{\mathrm{a}}$ \\
& C & $5,90-10,84$ & $7,64 \pm 1,17^{\mathrm{a}}$ \\
\hline
\end{tabular}




\begin{tabular}{lccc}
\hline $\mathrm{pH}$ & $\mathrm{A}$ & $6,9-7,5$ & $7,07 \pm 0,05^{\mathrm{a}}$ \\
& $\mathrm{B}$ & $6,7-7,5$ & $7,05 \pm 0,03^{\mathrm{a}}$ \\
& $\mathrm{C}$ & $6,6-7,5$ & $7,09 \pm 0,03^{\mathrm{a}}$ \\
\hline Suhu $\left({ }^{\circ} \mathrm{C}\right)$ & $\mathrm{A}$ & $25,1-31,5$ & $28,36 \pm 0,27^{\mathrm{a}}$ \\
& $\mathrm{B}$ & $25,2-32,6$ & $28,17 \pm 0,08^{\mathrm{a}}$ \\
& $\mathrm{C}$ & $25,1-32,7$ & $28,27 \pm 0,15^{\mathrm{a}}$ \\
\hline Salinitas (g/L) & $\mathrm{A}$ & $28-31$ & $29,42 \pm 0,10 \mathrm{a}$ \\
& $\mathrm{B}$ & $28-31$ & $29,48 \pm 0,09^{\mathrm{a}}$ \\
& $\mathrm{C}$ & $28-31$ & $29,35 \pm 0,08^{\mathrm{a}}$ \\
\hline Total Amonia Nitrogen & $\mathrm{A}$ & $0,1-1,0$ & $0,52 \pm 0,07^{\mathrm{a}}$ \\
$(\mathrm{mg} / \mathrm{L})$ & $\mathrm{B}$ & $0,1-1,0$ & $0,52 \pm 0,05^{\mathrm{a}}$ \\
& $\mathrm{C}$ & $0,1-1,0$ & $0,52 \pm 0,11^{\mathrm{a}}$ \\
\hline
\end{tabular}

Keterangan : Nilai merupakan rerata SD $(n=3)$. Superskrip alphabet yang berbeda menunjukkan nilai berbeda nyata antara pada tebar berbeda $(\mathrm{P}<0,05)$, ANOVA satu arah).

Description : Values are the mean \pm SD $(n=3)$. Different alphabet superscript showed significant difference values between different stocking densities $(\mathrm{P}<0.05$, one-way ANOVA)

Pada budidaya udang vaname sistem zwd, salah satu parameter penting yang perlu diperhatikan adalah kandungan total ammonia nitrogen (TAN). Kadar TAN mengindikasikan apakah sistem yang digunakan berjalan dengan baik atau tidak. Data Tabel 2 menunjukkan bahwa kadar TAN selama penelitian untuk semua perlakuan adalah 0,1-2,5 mg/L. Nilai ini masih berada pada kisaran yang layak untuk budidaya [15]. Penggunaan sistem zwd yang berbasis mikroba mempunyai peran dalam mengontrol Ninorganik pada media budidaya melalui manipulasi $\mathrm{C} / \mathrm{N}$ rasio dengan penambahan sumber karbon [16] ,[17].

\section{KESIMPULAN}

Berdasarkan hasil dari penelitian ini dapat disimpulkan bahwa :

1. Pada tebar udang vaname dengan menggunakan sistem ZWD tidak berpengaruh nyata terhadap kelangsungan hidup udang vaname tapi berpengaruh nyata terhadap pertumbuhan dan FCR.
2. Kinerja terbaik dijumpai pada perlakuan $A$ dengan pada tebar setara dengan 40 ekor $/ 0,1 \mathrm{~m}^{3}$.

3. Parameter fisika-kimia air masih berada pada kisararan yang layak untuk budidaya udang vaname.

\section{UCAPAN TERIMAKASIH}

Penulis mengucapkan banyak terimakasih kepada pimpinan Hatchery Windu Lestari Kelurahan Wolulu Kecamatan Watubangga Kabupaten Kolaka Provinsi Sulawesi Tenggara yang telah memfasilitasi tempat untuk penelitian ini.

\section{DAFTAR PUSTAKA}

[1] Kementerian Kelautan dan Perikanan (KKP). Kelautan dan Perikanan Dalam Angka. (https://kkp.go.id/setjen/satudata/page/1453kelautan-dan-perikanan-dalam-angka), 2018.

[2] Suantika G, Lumbantoruan G, Muhammad H, Azizah FFN, Aditiawati P. Performance of zero water discharge (ZWD) system with nitrifying bacteria and microalgae Chaetoceros calcitrans components in superintensive white shrimp (Litopenaeus vannamei) culture. J Aquac Res Dev., vol. 6, hal. 359,2015 
[3] Atjo H. Budi daya udang vaname supra intensif Indonesia. Dipresentasikan pada Launching Budi Daya Udang Vaname Super Intensif Indonesia. Barru. MAI-SCI Sulawesi Selatan (ID)., hal. 4, Okt 2013

[4] Samocha, T.M., Schveitzer, R., Krummenauer, D., \& Morris, T.C. Recent advance in super-intensive, zero-exchange shrimp raceway systems. Global Aquaculture., p. 70-71, 2012.

[5] Muhammad H, Situmorang ML, Djohan YA, Aditiawati P, Suantika G. Biological, Technical, and Financial Feasibilities Study of Zero Water Discharge (ZWD) System Applicationin Low Salinity White Shrimp (Litopenaeus vannamei Boone) Urban Aquaculture, Study Case: Gresik District, East Java, Indonesia. J Fisheries Livest Prod., vol 4, hal. 197, 2016.

[6] Zhao P, Huang J, Wang XH, Song XL, Yang $\mathrm{CH}$, Zhang XG, Wang GC. The application of bioflocs technology in high-intensive, zero exchange farming systems of Marsupenaeus japonicas. Aquaculture., vol. 354-355, hal. 97-106, 2012.

[7] Gao L, Shan HW, Zhang TW, Bao WY,Ma S. Effects of carbohydrate addition on Litopenaeus vannamei intensive culture in a zero-water exchange system. Aquaculture., vol. 342-343, hal. 89-96, 2012.

[8] Panjaitan P. Shrimp culture of Penaeus monodon with zero water exchange model (ZWEM) using molase. Journal of Coastal Development., vol. 14, hal.35-44, 2010.

[9] Verdegem MCJ. Nutrient discharge from aquaculture operations in function of system design and production environment. Review in Aquculture., vol. 5, hal. 158-171, 2013.

[10] Maia EP, Modesto GA, Brito LO, Galvez AO, Gesteira TCV. Intensive culture system of Litopenaeus vannameiin commercial ponds with zero water exchange and addition of molasses and probiotics. Revista de Biologia Marina y Oceanografia., vol. 51, hal. 61-67, 2016.
[11] Browdy CL, Hargreaves J, Tung H and Avnimelech Y. Biofloc Technology and Shrimp Disease Workshop. The Aquaculture Engineering Society, Copper Hill, VA USA., hal. 83-153, 2014.

[12] Syah R, Makmur, M Fahrus. Budidaya Udang Vaname Penebaran Tinggi. Media Akuakultur, hal 19-26; juni 2017.

[13] Utojo, Tangko A.M. Status, Masalah, dan Alternatif Pemecahan Masalah pada Pengembagan Budidaya Udang Vannamei (Litopenaeus vannamei) di Sulawesi Selatan. Media Akuakultur., vol. 3, hal. 118-125, 2008.

[14] Boyd CE. Dissolved - Oxygen Concentrations in pond Aquaculture. Global Aquaculture Alliance: Australia. 2012

[15] Schuler DJ, Boarman GD, Kuhn DD, Flick GJ. Acute toxicity ammonia and nitrite to Pacific white shrimp, Litopenaues vannamei, at low salinities. Journal of the Word Aquaculture Society., vol. 41, hal. 438-446, 2010.

[16] Nootong K, Pavasant P, Powtongsook S. Effects of Organic Carbon Addition in Controlling Inorganic Nitrogen Concentrations in a Biofloc System. Journal of The Aquaculture Society., vol. 42, hal. 339-446, 2011.

[17] Bosma RH, Verdegem MCJ. Sustainable aquaculture in ponds: Principles, practices and limits. Livestock Science., vol. 139, hal. 58-68. 2011. 